\title{
Tarih Ders Kitaplarında Kanıt Temelli Öğrenme Yaklaşımı: Ortaöğretim T.C. İnkılap Tarihi ve Atatürkçülük Ders Kitabı Örneği
}

DOI: $10.26466 /$ opus.825129

*

\author{
Mehtap Koldaş* - Akif Pamuk ** \\ * Doktora Öğrencisi, Marmara Üniversitesi, Eğitim Bilimleri Enstitüsü, İstanbul/Türkiye \\ E-Posta: mehtapkoldas@hotmail.com \\ ORCID: $0000-0002-2813-273 X$ \\ ** Dr. Öğr. Üyesi, Marmara Üniversitesi, Eğitim Fakültesi, İstanbul/Türkiye \\ E-Posta: akifpamuk@marmara.edu.tr \\ ORCID: $\underline{0000-0002-8147-611 X}$
}

\section{Öz}

Yapılandırmacı eğitim anlayışı ile birlikte tarih öğretiminde öğrencilerin tarihsel düşünme becerileri kazanması, ders sürecinde aktif olmaları amaçlanmaktadır. Öğrencilere becerilerin kazandırılmasında ise tarihsel kanttların (birinci el, ikinci el, farkl görüşlere ait kanıtlar) kullanılması ve bu kantların sorgulatılması etkili olmaktadır. Bu durum tarih derslerinde öğrencilerin küçük birer tarihçi gibi tarihsel kanutla etkileşime girmeleri ve kendilerinden beklenen tarihsel düşünme becerilerini kazanmalarını sağlamaktadır. Bu çalışmada kanıt temelli tarih öğretimi yaklaşımına göre 2019-2020 eğitimöğretim döneminde Talim Terbiye Kurulu tarafindan onaylanan Ortaöğretim T.C. Inkılap Tarihi ve Atatürkçülük ders kitabı incelenmiştir. Araştırmanın amacı Ortaöğretim T.C. İnkılap Tarihi ve Atatürkçülük ders kitabının kanıt temelli tarih öğretimine uygunluğunu ortaya koymaktır. Araştırmada nitel araştırma desenlerinden durum çalışması kullanılmış ve verilere doküman analizi ile ulaşılmıştır. Elde edilen verilerin analizi betimsel analiz ve içerik analizi kullanılarak yapılmıştır. Araştırmanın sonuçlarına göre, ders kitabında kanıt temelli öğrenme anlayışında öğrencinin tarihsel düşünme becerilerini kazanmaların sağlayan birinci elden kanıtların ikinci el kanıtlara göre daha az kullanıldı̆̆ tespit edilmiştir. Ayrıca tarih dersi öğretim programında belirlenen kazanımlar ve beceriler arasındaki ilişkinin ders kitabına yansımadığı ortaya çıkmıştır.

Anahtar Kelimeler: T.C. Inkılap Tarihi ve Atatürkçülük ders kitabı, kanıt temelli tarih öğretimi, tarihsel düşünme becerileri 


\title{
Evidence-Based Learning Approach in History Textbooks: Secondary Education Turkish Republic History of Revolution and Kemalism Textbook Example
}

\begin{abstract}
History teaching in the context of constructivist education aims to gain students historical thinking skills and to be active in the course process. Using historical evidences and questioning these evidences is effective in gaining skills to students. This enables students in history courses to interact with historical evidence like little historians. Students also acquire historical thinking skills expected of them. In this study, according to the evidence-based history teaching approach, the Secondary Education textbook of Turkish Republic History of Revolution and Kemalism [T.C. Inkilap Tarihi ve Atatürkçülük] has been examined. The aim of the research is to reveal the suitability to evidence-based history teaching of the Secondary Education textbook of Turkish Republic History of Revolution and Kemalism. The case study, one of the qualitative research designs, was used in the research and the data were obtained by document analysis. The obtained data were interpreted with descriptive analysis and content analysis. According to the results of the study, it was determined that first-hand evidence that enables students to gain historical thinking skills is used less than second-hand evidence in the understanding of evidence-based learning. Also it was revealed that the relationship between the acquisitions and skills determined in the history teaching program was not reflected in the textbook.
\end{abstract}

Keywords: Turkish Republic History of Revolution and Kemalism textbook, evidence-based history teaching, historical thinking skills. 


\section{Giriş}

1970'lerde İngiltere' de ortaya çıkan yeni tarih anlayışı ile birlikte tarih dersleri öğrenci merkezlilik, tarih çalışması, tarihçi becerilerini geliştirme, kanıtı yorumlama, kanitı analiz etme, nedensellik, empati gibi temel kavramlar üzerine inşa edilmiştir (Ata, 1999, s.2). Geleneksel tarih öğretimine karş1 geliştirilen yeni tarih öğretimi ile problem çözme, keşfetme gibi yöntemler kullanılmakta ve öğrencinin tarihsel düşünme becerilerini kazanması amaçlanmaktadır. Kendisine tarihçi rolü verilen öğrencinin, tarihi olay ve olguları sorgularken geçmişin tarihçiler tarafından nasıl yorumlandığını anlaması gerekmektedir. Bu bağlamda öğrenciler küçük birer tarihçi gibi görülmektedir. Bu bakış açısına göre tarihsel anlamanın gerçekleşmesi için öğrenciler tarafından tarihi delil ve belgelerin kullanılması gerekir. Aynı zamanda öğrencilerin tarihe ait düş gücü, tarihsel imgelem ve tarihsel duyarlılık gibi becerileri kazanmasına katkıda bulunur (Dilek, 2007, s.71). Fines (1994), öğrencilerin küçük birer tarihçi gibi çalışma nedenlerini şu şekilde açıklamaktadır:

“Tarihin nasıl yazıldığını, bize nasıl ulaştığını bilmeksizin öğrenilen tarih bir dizi iddianın ezberlenmesinden öteye gidemez. Ezberlenmiş bir tarih faydasızdır ve kullanılamaz. İyi öğrenme daima aktif öğrenmedir. Buna göre öğretmenden ziyade öğrenciler çalışır. Kanıt ile ilgili problemlerle başa çıkmayı öğrenmek meydan okumayı, zihinsel esnekliği, düşünsel süreçleri gerektirir ve bu çalışılan şeyin anlamlandırılmasına yardım eder. Aktif öğrenme anlamayı sağlar. Kaynak kullanımı ve kanıt ile ilgili problemleri çözmeye çalışmak, ikinci el tarihin nadiren verdiği gerçeklik hissini verir. Kanıtı zamanının bağlamında ele almak o zamana ait birçok görünüm hakkında iç görü (zamanı birçok yönüyle anlamayı) sağlar ve çalıştığımız konuyu hissetmeye yardım eder" (akt. Yapıcı, 2006, s.25).

Öğrenci, kanıta dayalı öğrenme yoluyla kanıtları kendi zihin dünyasında süreçten geçirdikten sonra bir anlam çıkarmaya başlamaktadır. Öğrencinin bilgi inşasını ve kendi anlamını oluşturmasında birinci el kaynaklar/kanıtlar ikinci el kaynaklardan/kanıtlardan daha etkili olmaktadır. Her öğrencinin kanıtları sorgulayarak ortaya çıkardığı kendi tarihsel inşası diğer öğrencilerden farklı olacaktır. Bu bağlamda nesnel ve genel geçer olarak kabul edilen tarih inşası yerine bireysel inşanın mümkün olduğu söylenebilir (Pamuk, 2014, s.116). Bazı Avrupa ülkelerinin (İngiltere, Fransa, İsviçre) tarih 
öğretimi programları ve ders örnekleri incelendiğinde özellikle kanıtı ve tarihsel bilgiyi sorgulama yoluyla öğrenciye, tarihi olay ve olguya dair birden çok yorumun olduğu algısı kazandırılmaktadır. Bu bağlamda yapılandırmacı tarih öğretiminin en temel amacı öğrenciye kendi bilgisini üretebileceği meydan okuma ortamları sunmaktır. Bu da birinci ve ikini el kaynakların sorgulanmasıyla olmaktadır (Yapıcı, 2006, s.58). Benzer biçimde Almanya'da hayat bilgisi dersinde tarihsel kanıtlar kullanılarak değişim ve süreklilik becerisi kazandırılmaya çalışılmaktadır (Pamuk, 2020).

Türkiye'de geleneksel tarih ders kitabı yazımlarımdan (Alaca, 2017) farklı olarak 2018 yılında tarih dersi öğretim programında yapılan değişim ile ders kitapları kanıt temelli eğitim anlayışı ile hazırlanmıştır. Tarih dersi öğretim programı ile öğrencilerin "birincil ve ikincil kaynaklarda yer alan kanıtları belirleme, analiz etme, yorumlama ve değerlendirmeyi içeren tarihe özgü yeterlilik ve becerileri geliştirmeleri, edindikleri bilgilerin doğruluğunu ve geçerliliğini sorgulayarak kanıtla desteklenen çıkarımlarda bulunmaları" amaçlanmaktadır (Talim ve Terbiye Kurulu Başkanlığı [TTKB], 2018, s.12). Öğrencilerin küçük birer tarihçi gibi kantları sorgulayıp beceri kazanmaları beklenmektedir. Birinci ve ikinci elden kaynakların/kantların sorgulanması ve etkinliklerle birlikte öğrencilere tarihsel düşünme becerileri olarak; tarihsel kavrama, tarihsel analiz ve yorum, değişim ve sürekliliği algılama, tarihsel sorun analizi ve karar verme, tarihsel sorgulamaya dayalı araştırma, neden- sonuç ilişkisini kurma ve tarihsel empati kazandırılması amaçlanmaktadır.

Ders kitaplarındaki kaynaklara yöneltilen sorular ile öğrencinin en alt düzeyden en üst düzey düşünme becerisine ulaşması hedeflenmektedir (Alaca, 2019). Kazandırılmak istenen beceriler için hazırlanan sorular verilen kazanımlara göre şekillenmektedir. Bu bağlamda öğretim sürecinde öğrenciye kazandırılması düşünülen kazanımlar bilgi, beceri, tutum ve değerlerden oluşmaktadır. Bilgi, bilişsel alanla kazandırılacakların ifadesiyken; beceri, devinişsel alanla; tutum ve değer ise duyuşsal alanla kazandırılacakların ifadesidir. Bilişsel alan, öğrenme esnasında zihinsel değişimlerle ilgilenir. Duyuşsal alan, öğrenme sürecinde ortaya çıkan duygusal değişmelere; devinişsel alan ise yetenek alanındaki değişmelere odaklanır. Üç öğrenme alanı da birbiri ile ilişkilidir (Çolak, 2008, s.14). Bloom bilişsel alandaki yeterlilik kategorilerini bilgi, kavrama, uygulama, analiz, sentez ve değerlendirme olarak listelemiştir. Bloom'a (1956) göre en altta bilgi düzeyi en üstte ise 
değerlendirme düzeyi bulunmaktadır. Öğrenciler belirli bir bilgi düzeyine sahip olduktan sonra üst düzey becerilere ulaşabilmektedirler (akt. Şimşek, 2014, s.217).

Yapılandırmacı bir tarih öğretimi anlayışı ile öğrencilerin tarih derslerinde tarihsel düşünme becerilerini kazanması amaçlanmaktadır. Tarihsel düşünme sürecinin unsurları ise tarihsel bilgi, mantıksal düşünme süreçleri, imgelem, çağrışımsal düşünme, tarihsel dil ve deneyimsel anlamadan oluşur ve tarihsel düşünmenin gelişiminde kanıtların temini, tarihçinin çalışma yolların gösterme, analiz ve senteze dayalı etkinlikler önemli rol oynamaktadır (Dilek ve Alabaş, 2010). Dolayısıyla öğrencide tarihsel düşünme becerisi geliştirmede tarihsel kanıtlar/kaynaklar ve bunların sorgulanması işe koşulmaktadır. Öğrenme-öğretme sürecinde tarihsel kanıtların etkili bir şekilde kullanımında ise kanıt temelli öğrenme işe koşulmaktadır. Kanıt temelli öğrenme, öğrencilerin grup veya bireysel çalışmalar ve sorgulamalar yoluyla farklı türden (birinci ve ikinci elden) kanıtları kullanmaları, farklı kaynaklarla karşı karşıya kalarak bir takım becerileri kazanmaları esasına dayanan zihinsel etkinlikler bütünüdür (Alabaş, 2007). Kanit temelli öğrenme "zıtlıkları, çelişkileri, farklı bakış açılarını bir arada vererek düşünsel ve duyuşsal anlamda öğrencileri sorunun içinde var etmenin yolunu da öğretmene ve öğrenciye" sunar (Kabapınar, 2019: IV). Bu bağlamda tarihsel düşünme becerilerini kazanmak için tarih ders kitaplarının kanıt temelli tarih öğretimi anlayışına göre hazırlanması ve ders kitaplarında kanıtlara yönelik soruların yer alması önemlidir. Öğrencilerin sorulan sorular ve etkinlikler üzerinden tarihsel düşünme becerilerini kazanması beklenmektedir. Bu bağlamda araştırmanın problem cümlesini "tarih ders kitaplarında kanıt temelli öğrenme yaklaşımı nasıl kullanılmaktadır?" sorusu oluşturmaktadır. Araştırmanın alt problemleri ise şunlardır:

1. Tarih ders kitaplarında kanıt temelli öğrenme yaklaşımında hangi tür kanitlar kullanilmaktadır?

2. Tarih ders kitaplarında kanıt temelli öğrenme yaklaşımı ile hangi beceriler kazandırılmaktadır?

3. Tarih ders kitaplarında kanıt temelli öğrenme yaklaşımında kazanım, beceri ve etkinlik arasında ilişki nasıldır? 


\section{Yöntem}

\section{Araştırma Modeli}

Bu çalışmada tarih ders kitaplarının kanıt temelli öğrenme yaklaşımına uygunluğunu tespit etmek için en uygun nitel araştırma deseni olarak durum çalışması tercih edilmiştir. Nitel araştırma araştırmacının bilgi ve deneyimleri ile gerçekliğin bulunduğu bağlamda anlamlandırılmasını temel alan bir yaklaşımdır. Nitel araştırmacılar çoğunlukla belli bir durumun ötesinde genelleme yapmazlar (Büyüköztürk, Çakmak, Akgün, Karadeniz, Demirel, 2012, s.235 ). Nitel araştırma kuram oluşturmayı temel alan anlayışla sosyal olguları içinde bulunduğu çevre içinde araştırmayı ve anlamayı ön plana çıkaran yöntemdir (Yıldırım ve Şimşek, 2013, s.45). Durum çalışması "güncel bir örnek olayı ya da durumu derinlemesine bağlam ve durum arasındaki sınırlar belirgin olmadığında kendi gerçek dünyasında otantik ortamda incelemekle ilgilidir" (Yin,2014, akt. Saban ve Ersoy, 2016, s.118). Ayrica araştırmada nitel araştırmalarda kullanılan tipik durum örneklemesi tercih edilmiştir. Tipik durum örneklemesi araştırma problemi ile ilgili evrende yer alan çok sayıdaki durumdan tipik olan seçilir ve bunun üzerinden bilgi toplanması gerekir. Burada esas olan sıra dışı olmayan ortalama bir durumun seçilmesidir (Büyüköztürk vd., 2012, s.91). Araştırmada Talim Terbiye Kurulu Başkanlığ tarafindan 18.04.2019 tarih ve 8 sayılı kararıyla 2019-2020 eğitim öğretim döneminden itibaren okutulması kabul edilen 12. sinıflar için hazırlanan "Ortaöğretim T.C. İnkılap Tarihi ve Atatürkçülük" ders kitabı (Demirtaş, 2019) incelenmiştir. 12. sınıf İnkılap Tarihi dersi konu itibarıyla günümüze yakın bir süreci ele almaktadır. Buradan hareketle ders kitabından birinci elden kanıtların daha fazla kullanılacağı varsayılmıştır.

\section{Veri Toplama Araçlan}

Araştırmanın durumuna uygun olarak nitel araştırma veri toplama araçlarından doküman analizi tercih edilmiştir. Doküman analizi, araştırılması hedeflenen olgu ve olayları içeren yazılı metinleri incelemeyi kapsamaktadır. Dokümanlar nitel araştırmalarda etkili bir şekilde kullanılması gereken bilgi kaynaklarıdır (Yıldırım ve Şimşek, 2013, s.217). Araştırmanın problem cümlesi bağlamında bir doküman olarak Ortaöğretim T.C. İnkılap Tarihi ve Atatürkçülük ders kitabı inceleneceği için doküman analizi tercih edilmiştir. 


\section{Verilerin Analizi ve Yorumlanması}

Ortaöğretim T.C. İnkılap Tarihi ve Atatürkçülük ders kitabının incelenmesinde betimsel analiz ve içerik analizi kullanılmıştır. Betimsel analiz ile elde edilen veriler belirlenen temalara göre özetlenir, yorumlanur ve doğrudan alıntılara yer verilir. Veriler düzenlenmiş ve yorumlanmış bir şekilde okuyucuya sunulur. Bu bağlamda elde edilen veriler önce açık bir şekilde betimlenir. Daha sonra bu betimlemeler yorumlanır, neden-sonuç ilişkisi kurularak irdelenir ve sonuçlara ulaşılır (Yıldırım ve Şimşek, 2013, s.256). Ortaöğretim T.C. İnkılap Tarihi ve Atatürkçülük ders kitabından doğrudan alıntılar yapılmıştır ve bu alıntılar temalar altına yerleştirilmiştir.

Elde edilen veriler içerik analizi yoluyla yorumlanmıştır. İçerik analizi gözleme dayalı materyallerden çok mülakat, günlükler ve dokümanlar üzerinden analizi kapsamaktadır. İçerik analizi, nitel verilerin temel tutarlılığ ve verilerin anlamlandırılması için kullanılmaktadır. İçerik analizi ile bulunan anlamlara da örüntü ya da tema denilmektedir (Patton, 2014, s.453). Ortaöğretim T.C. İnkılap Tarihi ve Atatürkçülük ders kitabı incelenerek birinci el, ikinci el ve genel ağ kaynakları tespit edilmiştir, inceleme sonucunda hangi becerilerin kazandırıldığı analiz edilmiştir ve kazanım, beceri, etkinlik arasındaki ilişki yorumlanmıştır.

\section{Bulgular}

\section{Tarih Ders Kitaplarında Kullanılan Kanıt Türleri}

Ortaöğretim T.C. İnkılap Tarihi ve Atatürkçülük ders kitabında kullanılan kanıtlar ders kitabını hazırlayanlar tarafından birinci elden kaynak, ikinci elden kaynak ve genel ağ kaynakları olarak üçe ayrılmıştır. Genel ağ kaynakları internet üzerinden Dergipark vb. sitelerde hazırlanan makalelerden alınmıştır. Aşağıda tablo 1'de ünitelere dair kanıt türleri verilmiştir. 
Tablo 1. 12.Sinı Üniteler

\begin{tabular}{llll}
\hline 12.Sınıf Üniteler & $\begin{array}{l}\text { Birinci elden } \\
\text { kaynaklar }\end{array}$ & $\begin{array}{l}\text { İkinci elden } \\
\text { kaynaklar }\end{array}$ & $\begin{array}{l}\text { Genel ağ } \\
\text { kaynakları }\end{array}$ \\
\hline 20. Yy. Başlarında Osmanlı Devleti ve Dünya & 7 & 8 & 14 \\
\hline Milli Mücadele & 5 & 17 & 11 \\
\hline Atatürkçülük Ve Türk İnkılabı & 2 & 7 & 15 \\
\hline İki Savaş Arasındaki Dönemde Türkiye Ve Dünya & 3 & 7 & 7 \\
\hline II. Dünya Savaşı Sürecinde Türkiye Ve Dünya & 2 & 4 & 3 \\
\hline II. Dünya Savaşı Sonrasında Türkiye Ve Dünya & 8 & 5 & 1 \\
\hline Toplumsal Devrim Çağında Dünya Ve Türkiye & - & 8 & 3 \\
\hline 21. Yüzyılın Eşiğinde Türkiye ve Dünya & - & 4 & 15 \\
\hline
\end{tabular}

1. ünitede kanıt olarak verilmediği halde birinci el niteliği taşıyan 10 görsel bulunmaktadır fakat kanıt temelli eğitim anlayışna göre ders kitaplarında kullanılan her görsele veya alıntıya dair soru sorulması ve öğrencinin çıarımda bulunarak beceri kazanması amaçlanmaktadır. Ders kitabında görsellere herhangi bir soru yöneltilmemiştir. Özellikle 3. kazanımda Çanakkale Cephesi'ne dair birçok birinci elden kaynak bulunmasına rağmen ders kitabında bu kaynaklar kullanılmamıştır. Döneme dair birinci elden kaynak yoğun olmasına rağmen kitapta kullanılmaması eksiklik olarak görülmekte ve kanıt temelli tarih öğretimi yaklaşımıyla örtüşmemektedir. 1 . ünite ve diğer üniteler de aynı şekilde programın amaç ve felsefesiyle uyumlu değildir (TTKB, 2018, s.12). Ayrıca öğrencilerin kaynakları sınıflandırmasına izin verilmeden kaynaklar ders kitabı yazarı tarafından birinci ve ikinci el kaynak şeklinde sınıflandırılmıştır. Öğrencilerin kanıtları belirlemesinde ve sınıflandırmasında ders kitabının öğretim programı ile çeliştiği ifade edilebilir. Ayn zamanda kullanılan kaynakların kanıt isimlendirilmesi yapılmamıştır.

2. ünite, 3. ünite, 4. ünite ve 8. ünitede kazanımlar arası kaynak dağılımına bakıldığında birinci ve ikinci el kaynak kullanımı açısından denge olmadığı ve kanıt çeşitliliğinin sağlanmadığı söylenebilir. Başka bir ifadeyle ilgili üniteler öğrencilerin birinci elden kaynaklarla karşılaşıp küçük birer tarihçi gibi çıarımda bulunması bağlamında yetersiz kaldığı söylenebilir.

Ünitelerde yer alan kanitları daha da somutlaştırmak gerekirse 5.ünite incelendiğinde 3. kazanımda, II. Dünya Savaşı yıllarına dair birinci elden kanıtın oldukça fazla olmasına rağmen ders kitabında kullanılmaması eksiklik olarak görülmektedir. Benzer biçimde 7. ünitede Kıbrıs Barış Harekatı'na dair birinci el çok çeşitli kaynaklar (anılar, günlükler, mektuplar vb.) olmasına rağmen birinci el kanıt kullanılmamıştır. Diğer taraftan 6 . ünitede 
diğer ünitelerin aksine kullanılan birinci ve ikinci el kanıt dağılımı dengelidir.

Ortaöğretim T.C. İnkılap Tarihi ve Atatürkçülük ders kitabının ünitelerine kaynak kullanımı açısından bakıldığında kaynak sınıflandırmasını kitabın yazarı tarafından yapıldığı görülmektedir.

İlgili ders kitabının kanıt temelli öğrenme anlayışına göre hazırlandığ söylenebilir. Fakat kazanımlar incelendiğinde kaynak çeşitliliğine dikkat edilmediği görülmektedir. Dönem itibarıyla birinci el kaynaklara ulaşılabilir olmasına rağmen kitapta ağırlıklı olarak ikinci el kaynaklar/kanıtlar kullanılmıştır. Birinci el kaynaklar/kanıtlar ise görsel olarak verilmiş ve kanıtı sorgulama soruları kullanılmamıştır. Kanıt temelli öğrenme yaklaşımında verilen her kanıtı/görselin sorgulatılması ve öğrencinin beceri kazanması için kullanılması gerekmektedir fakat incelenen ders kitabında bu anlayışa uyulmadığı görülmektedir.

\section{Ders Kitaplarnda Kazandırılmak İstenilen Tarihsel Düşünme Becerileri}

Kanıt temelli öğrenme anlayışına göre hazırlanan Ortaöğretim T.C. İnkılap Tarihi ve Atatürkçülük ders kitabında yer alan kanıtlar incelenerek yöneltilen soru ve etkinliklerle öğrencilerin tarihsel düşünme becerilerinden hangilerini kazandığı tespit edilmeye çalışılmıştır. Bu bağlamda Tablo 2'de ders kitabında kazandırılmak istenilen tarihsel düşünme becerilerine yer verilmiştir.

Tablo 2. Tarihsel Düşünme Becerileri

\begin{tabular}{ll}
\hline Tarih Ders Kitabında Kazandırılmak İstenen Beceriler & f \\
\hline Tarihsel Analiz ve Yorum & 100 \\
\hline Tarihsel Kavrama & 40 \\
\hline Değişim ve Sürekliliği Algılama & 15 \\
\hline Neden- Sonuç İlişkisi Kurma & 10 \\
\hline
\end{tabular}

Ortaöğretim T.C. İnkılap Tarihi ve Atatürkçülük ders kitabında tarihsel analiz ve yorum, tarihsel kavrama, değişim ve sürekliliği algılama, nedensonuç ilişkisi kurma becerileri yer almaktadır. En fazla frekansa sahip beceri tarihsel analiz ve yorum, en az frekansa sahip beceri ise neden- sonuç kurma ilişkisi kurma becerisidir. 


\section{Tarihsel Kavrama}

Tarihsel kavrama becerisi tarihsel düşünme becerilerinin alt basamağında bulunmaktadır. Bloom taksonomisine göre bilgi ve kavrama basamağında tarihsel kavrama becerisi kazandırılabilir. T.C. İnkılap Tarihi ve Atatürkçülük dersi öğretim programında da belirtildiği gibi "tarihsel metinleri kavramak ayrıca öğrencilerin tarihsel yaklaşım edinmelerini yani geçmişteki olayları yaşandığı dönemin şartları ve kavramlarıyla ele alarak o dönemi yaşayanların bakış açısıyla inceleyebilmelerini gerektirir" (TTKB, 2018, s.13).

İtilaf Devletlerinin Osmanlı Devleti'ni paylaşmaya yönelik imzaladıkları gizli antlaşmaları araştırınız. Daha sonra Harita 1.4'te Mondros Ateşkes Antlaşması'yla birlikte Anadolu'da işgal edilen yerler ile bu gizli antlaşmaların maddelerini karşılaştırınız.

\section{Görsel 1.}

İlgili ders kitabında tarihsel kavrama becerisini kazandırmaya yönelik yeterli sayıda soru sorulmamıştır. Ortaöğretim T.C. İnkılap Tarihi ve Atatürkçülük ders kitabında Görsel 1'deki (Demirtaş, 2019, s.41) soruda öğrencinin antlaşma maddeleri üzerinden bir karşılaştırma yapması istenmektedir. Sorunun içeriğine bakıldığında ise kavrama düzeyinde olduğu söylenebilir. Kanıt temelli öğrenme anlayışında sorular öğrencinin sınıf içerisinde cevaplandıracağı nitelikte olmalıdır fakat buradaki soruya bakıldığında öğrencinin araştırma yapmasının beklendiği görülmektedir.

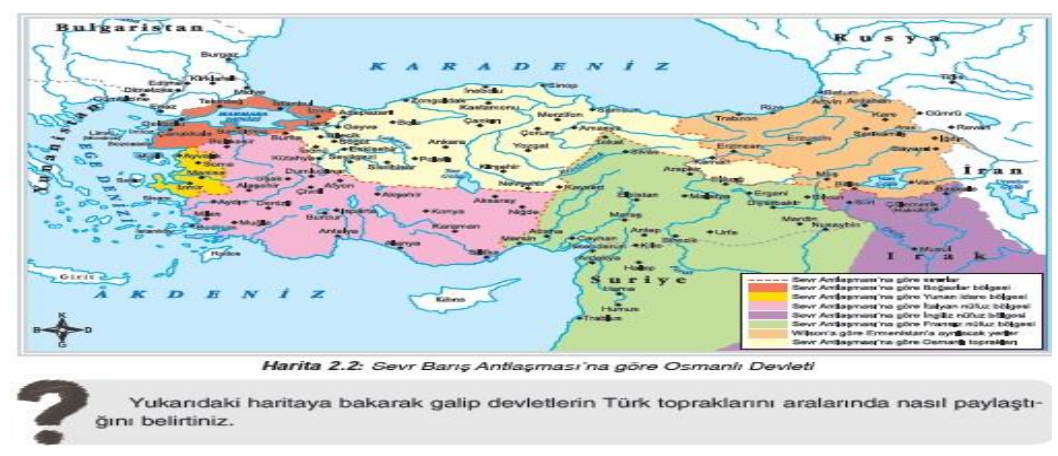

Görsel 2.

Görsel 2'de ise (Demirtaş, 2019, s.71) öğrencinin kavrama becerisini kazanması için harita üzerinden bir çıkarım yapması istenmiştir. Bloom takso- 
nomisine göre öğrenciden beklenen becerilerin kavrama basamağına denk geldiği ifade edilebilir.

\section{Tarihsel Analiz ve Yorum}

Tarihsel analiz ve yorum becerisi öğrencilere kazandırılmaya çalışılan üst düzey tarihsel düşünme becerilerindendir. Bloom taksonomisinde analiz ve sentez basamağına denk geldiği söylenebilir. T.C. İnkılap Tarihi ve Atatürkçülük dersi öğretim programındaki "Tarihsel analiz ve yorum yapabilmek için öğrenciler tarihsel kavrama becerilerini kullanmalıdır (TTKB, 2018, s.16)." ifadesinden de anlaşılacağı gibi öğrencinin analiz seviyesine gelebilmesi için kavrama becerisini edinmesi gerekmektedir fakat ilgili ders kitabında öğrenciye tarihsel kavrama becerisini kazandırmadan tartışınız soru köküyle tarihsel analiz ve yorum becerisinin kazandırılmaya çalışıldığı görülmektedir. Ayrıca ilgili ders kitabında analiz düzeyine yönelik soru ve etkinlik sayısı oldukça azdır.

\section{Meşrutiyetin yeniden ilan edilmesi Türk toplumuna neler kazandırmış olabilir? Tartışınız.}

\section{Görsel 3.}

Görsel 3'teki (Demirtaş, 2019, s.22) soru öğrencinin analiz ve yorum yapabilmesine yöneliktir. Öğrencinin edindiği bilgilerden yola çıkarak bir yorum yapması beklenmektedir. Bloom taksonomisinde analiz basamağına denk geldiği söylenebilir.

Basının ve kamuoyunun Türk dış politikasındaki gelişmeler karşında birlik içinde hareket etmesi sizce ne anlam ifade etmektedir? Bu durumun önemini tartışınız.

\section{Görsel 4.}

Görsel 4'te (Demirtaş, 2019, s.208) yöneltilen soruda ise öğrencinin kendi yorumunu ifade etmesi beklenmektedir. Bundan dolayı tarihsel analiz ve yorum becerisini kazandırmaya yönelik olduğu söylenebilir. 
Türk-Yunan ilişkilerinin tarihî seyrini göz önünde bulundurarak dostluk, düşmanlık, komşuluk, iyi niyet, siyasi gerçeklik gibi kavramların tartışıldığı bir drama çalışması yapınız.

\section{Görsel 5.}

Görsel 5 (Demirtaş, 2019, s.148) tarihsel analiz ve yorum becerisini kazandırmaya yönelik etkinliklerden biridir. Öğrencilerin Türk ve Yunan ilişkileri bağlamında dostluk, düşmanlık, komşuluk gibi kavramları yorumlayıp ardından drama yapmaları istenmiştir. Bu etkinlik ile öğrencinin Türk ve Yunan ilişkilerinin tarihi açısından tarihsel analiz ve yorum becerisi ve tarihsel empati kazanması beklenmektedir. Bu etkinlik Bloom taksonomisinde sentez basamağına denk gelmektedir. Öğretim programında kazand1rılması amaçlanan becerilerden biri de tarihsel empatidir. Ders kitabında tarihsel empati kazandırmak için verilen kaynaklarda mikro anlatılar ve bireylerin sosyal hayatına dair anlatılar sinırlı sayıdadır.

Ortaöğretim T.C. İnkılap Tarihi ve Atatürkçülük ders kitabında kanıtı sorgulamaya yönelik sorular ve verilen etkinliklerle öğrencilere yoğunlukla tarihsel analiz ve yorum becerisi kazandırılmaya çalışıldığı ifade edilebilir. Ders kitabında verilen birinci el, ikinci el kaynakları ve genel ağ kaynaklarına yalnızca görsel olarak yer verilmiş olup kanıtlara soru yönlendirilmemiştir. Bu bağlamda mevcut durum, öğretim programında yer alan “Öğrenciler tarihsel metni analitik bir bakış açısıla inceleyebilen iyi bir tarih okuyucusu olmalıdır. Öğrencilere; "Amaca uygun okuyor muyum?", "Öğrenmek istediğim bu mu?" gibi sorular sordurmak gerekir" tarihsel analiz ve yorum açıklaması ile çelişmektedir (TTKB, 2018, s.15).

Öğrencinin tarihsel analiz ve yorum becerisini kazanabilmesi için öğretim programında belirtilen "ele alınan her konuyla ilgili birden fazla kaynak kullanmak gerekir"'(TTKB, 2018, s.15) maddesi ile çelişen bir başka durum ise; öğrencinin tarihsel analiz ve yorum becerisi kazanabilmesi için konuya dair farklı bakış açılarını ders kitabında deneyimlememesidir. Öğrencinin çok boyutlu bakış açısı kazanmasını sağlayan birinci elden ve ikinci elden kanıtlara yer verilmediği görülmektedir. 


\section{Değişim ve Sürekliliği Algılama Becerisi}

Değişim ve sürekliliği algılama becerisi 2018 yılında tarih öğretim programına yeni eklenmiş üst düzey becerilerindendir. Değişim ve sürekliliği alg1lama becerisi ile öğrencilerin geçmişten günümüze değişen ve devam eden durumları fark etmeleri amaçlanmaktadır fakat ders kitabında değişim ve sürekliliği algılama becerisini kazandırmaya yönelik sınırlı sayıda soruya yer verilmiştir.

Mustafa Kemal'in çocukluğundan itibaren kendisi için en iyi, en doğru olanı düşünme yeteneği ve kararlarında gösterdiği bağımsız tavrı bundan sonraki hayatını nasıl etkilemiş olabilir? Değerlendiriniz.

\section{Görsel 6.}

Görsel 6'da (Demirtaş, 2019, s.13) öğrencilerin Mustafa Kemal'in çocukluk döneminden sonraki hayatına etkisi değişim ve sürekliliği algılamasına yönelik soru yöneltilmiştir. Bloom taksonomisine göre analiz basamağına denk geldiği söylenebilir.

Atatürk Dönemi'nde Türkiye Cumhuriyeti'nin en problemli dış politika ilişkilerini Fransa ile yaşamasının iki devlet arasındaki geçmişle ilgisi var mıdır? Düşüncelerinizi açıklayınız.

\section{Görsel 7.}

Görsel 7'ye (Demirtaş, 2019, s.150) bakıldığında ise öğrenciden geçmişten günümüze Fransa ile olan ilişkileri değerlendirmesi istenerek değişim ve süreklilik becerisi kazandırılmak istenmiştir. Bloom taksonomisine göre analiz basamağında olduğu söylenebilir.

\section{ETKINLIK}

Şubat 2001 Krizi ve sonrasını konu alan bir gazete haberi hazırlayınız. Kriz sonrası Türkiye ile bugünkü Türkiye'nin refah seviyesini karşılaştırınız.

Görsel 8.

Görsel 8'deki (Demirtaş, 2019, s.247) etkinlikte görüldüğü gibi öğrencinin 2001 ve günümüzdeki durumunu kriz bağlamında değişim ve süreklilik açısından ele alması beklenmektedir.

Öğretim programında ifade edildiği gibi (TTKB, 2018, s.14) ders kitabında biyografiler, birinci el niteliğinde görseller bulunmaktadır fakat bunları 
sorgulatacak, dönemle bağını kurmasını sağlayacak soru ve etkinlik bulunmamaktadır. Öğrencinin değişim ve sürekliliği algılama becerisini kazanması için sunulan gazete haberlerinin, görsellerin vb. birbiri ile karşılaştırılması, sorgulatılması, yorumlatılması açısından yetersiz kalmıştır.

\section{Neden-Sonuç İlişkisini Kurma Becerisi}

Neden- sonuç ilişkisini kurma becerisi 2018 yılında tarih öğretim programına yeni eklenmiş üst düzey becerilerden biridir ve Bloom taksonomisinde analiz basamağına denk gelmektedir.

Erzurum Kongresi, bölgesel bir çalışma olarak düşünülmüşken bu kongreden millî kararların çıkmış olmasının nedenleri neler olabilir? Çıkarımda bulununuz.

\section{Görsel 9.}

Görsel 9'da (Demirtaş, 2019, s.59) öğrencilere yöneltilen soruda Erzurum Kongresi'nin farklı boyutlarının nedenleri ortaya çıarılmaya çalışılmaktadir.

Osmanlı Devleti'nin 400 yıl hâkimiyet sürdüğü Kudüs topraklarının Arap-İsrail Savaşları sonunda İsrail'in eline geçmesi İslam dünyası adına nasıl sonuçlar doğurmuş olabilir? Tartışınız.

\section{Görsel 10.}

Görsel 9 ile aynı şekilde Görsel 10’da (Demirtaş, 2019, s.219) da Arapİsrail savaşları sonucunda ortaya çıkan başka bir sorunun sonuçları saptanmaya çalışılmaktadır. Öğrencinin neden-sonuç ilişkisinin bağlamını kurması beklenmektedir. Soruların sonunda bulunan çıkarımda bulununuz, tartısınız gibi ifadelerle soruların cevabı öğrenciden yazılı olarak istenirse bunun sınıf içindeki etkileşimi azaltıcı bir etkiye sahip olacağından bahsedilebilir.

Öğrencilerin neden-sonuç ilişkisi kurma becerisini kazanmasını sağlayacak kaynakların ve buna bağlı soruların eksik olduğu söylenebilir. Bu bağlamda 12. sınıf T.C. İnkılap Tarihi ve Atatürkçülük dersi ile kazandırılmak istenen amaçlarla (TTKB,2018, s.12) ders kitabı çelişmektedir. Ortaöğretim T.C. İnkılap Tarihi ve Atatürkçülük ders kitabında kanıt sorgulama soruları ve verilen etkinlikler incelendiğinde ağırlıklı olarak öğrencilere tarihsel analiz ve yorum becerisi kazandırılmak istenmiştir. Alt düzey beceri bağlamın- 
da öğrencinin kavrama düzeyine yönelik soruların yetersiz olması eksiklik olarak ifade edilebilir. Ayrıca ilgili ders kitabında tarihsel kavrama, nedensonuç ilişkisi kurma, değişim ve sürekliliği algılama becerilerine ise çok az yer verilmiştir. Sonuç olarak kazandırılmak istenen tarihsel düşünme becerilerinin sayısı bakımından denge bulunmamaktadır.

\section{Tarih Ders Kitaplarında Kazanım, Beceri ve Etkinlik İlişkisi}

Kanıt temelli eğitim anlayışına göre hazırlanan Ortaöğretim T.C. İnkılap Tarihi ve Atatürkçülük ders kitabının öğretim programında yer alan kazanım, kazanıma dair verilen sorularla kazandırılmaya çalışılan beceri ve etkinlik arasında ilişki incelenmiştir. Öğretim programında verilen kazanımlar alt düzey ve üst düzey becerileri kazandırmaya yöneliktir. Kazanım cümlelerinde yer alan "kavrar", "açıklar" gibi yüklemler alt düzey becerileri kazandırmayı amaçlarken, "değerlendirir" ve "analiz eder" gibi yüklemler ise üst düzey becerileri kazandırmayı amaçlamaktadır. Tablo 3'te kazanım, beceri ve etkinlik arasında uyum/ denge olmayan kazanımlara yer verilmiştir.

Tablo 3. Kazanım, Beceri ve Etkinlik Arasında Uyum Olmayanlar

\begin{tabular}{|c|c|c|}
\hline Kazanım & Beceri & Etkinlik \\
\hline $\begin{array}{l}\text { 1.2. 20. yüzyıl başlarında Osmanlı } \\
\text { Devleti'nin siyasi, sosyal ve } \\
\text { ekonomik durumunu analiz eder. }\end{array}$ & Tarihsel analiz ve yorum & $\begin{array}{l}\text { Sultan II. Abdülhamid'in tahttan indirilmesinden sonra } \\
\text { yaşanan gelişmelerle ilgili olarak Ayşe Sultan'ın "Babam } \\
\text { Sultan Abdülhamit" isimli hatıratını okuyunuz. }\end{array}$ \\
\hline $\begin{array}{l}\text { 2.4. Doğu ve Güney } \text { Cephelerinde } \\
\text { verilen mücadelelerin } \\
\text { bağımsılkemizin } \\
\text { kavrar. }\end{array}$ & $\begin{array}{l}\text { Tarihsel kavrama } \\
\text { Tarihsel analiz ve yorum }\end{array}$ & $\begin{array}{l}\text { Doğu Cephesi'nin kahramanı olan Kazım Karabekir } \\
\text { Paşa'nın sözlerini yazdığı ve bestelediği “Türk Yılmaz } \\
\text { Marşı” üzerine araştırma ödevi ve soru sorulmuştur. }\end{array}$ \\
\hline $\begin{array}{l}\text { 5.3. II. Dünya Savaşı́nın } \\
\text { sonuçlarını değerlendirir. }\end{array}$ & $\begin{array}{l}\text { Tarihsel analiz ve yorum } \\
\text { Değişim ve sürekliliği } \\
\text { algılama }\end{array}$ & Etkinlik verilmemiştir. \\
\hline $\begin{array}{l}\text { 7.2. } 1960 \text { 'lardan itibaren Türk dış } \\
\text { politikasını etkileyen önemli } \\
\text { gelişmeleri kavrar. }\end{array}$ & $\begin{array}{l}\text { Tarihsel analiz ve yorum } \\
\text { Değişim ve sürekliliği } \\
\text { algılama }\end{array}$ & Kıbrıs gazileri ile sözlü tarih çalışması. \\
\hline
\end{tabular}

1.ünitenin birinci kazanımına bakıldığında kazanımın analiz seviyesinde olduğu ve üst düzey beceri kazandırmaya yönelik olduğu söylenebilir. Kaynaklara ve ara metinlere yöneltilen sorulara bakıldığında ise kazanımın genelinde öğrencilere tarihsel analiz ve yorum becerisi kazandırılmaya çalı- 
şılmıştır. Ünite içerisinde kavrama düzeyinde beceri kazandıracak soru bulunmamaktadır.

Öğretim programında öğrencinin tarihsel analiz ve yorum becerisi kazanması için öncelikle tarihsel kavrama becerisi kazanması gerektiği vurgulanmıştır; fakat ders kitabına bakıldığında bu durumun öğretim programı ile çeliştiği görülmektedir. Öğrencinin analiz düzeyinde beceri kazanmasını amaçlayan kazanıma dair verilen etkinlik beceriyi karşlayamamaktadır. Yapılandırmacı tarih öğretimine göre öğrencinin sınıftaki akranlarıyla birlikte işbirlikli öğrenme çerçevesinde öğretmenin rehberliğinde tarih bilgisini inşa etmesi beklendiğinden, sınıf dışında verilen bireysel okuma etkinlikleri öğrencinin analiz düzeyinde beceri kazanması açısından yetersiz kaldığ söylenebilir. Aynı zamanda etkinliklere dair yönerge hazırlanmaması bir diğer eksiklik olarak göze çarpmaktadır. Yönergeli etkinlikler yerine okuma parçaları tercih edilmiştir.

2. üniteye bakıldığında 1. ünite ile benzer biçimde kazanım, beceri ve etkinlik arasında uyumsuzluk olduğu görülmektedir. Kazanım, kavrama düzeyinde ele alınmıştır ve alt düzey beceriler kazandırmaya yöneliktir. Beceri bağlamında ise tarihsel kavrama düzeyine çok fazla yer verilmese de öğrenciye analiz ve yorum yapması beklenen sorular sorulmuştur. Kazanımda tarihsel analiz ve yorum becerisi kazandırılmak istenmiştir. Buradaki temel sorunun kazanım bağlamında alt düzey becerilerin ihmal edilerek doğrudan üst düzey beceri kazandırma kaygısı olduğu söylenebilir. Bu açıdan kavrama düzeyindeki kazanımda, tarihsel kavramanın ihmal edilmesi kazanım ve beceri açısından uygun olmadığını ortaya çıkarmaktadır.

5. üniteye bakıldığında ise diğer ünitelerin kazanımlarından farklı olarak üst düzey bir kazanım verilmiş fakat kazanıma dair etkinlik verilmemiştir. Kazanım üst düzey becerileri amaçlamaktadır. Kazanıma uygun olarak üst düzey beceri kazandıracak sorular yöneltilmiştir fakat kavrama düzeyinde soru verilmediği için öğrenci bilişsel olarak hazırlanmadan analiz seviyesinde beceri kazanması beklenmektedir. Bir diğer eksik yanı ise değerlendirme boyutundaki kazanıma dair etkinliğe yer verilmemiş olmasıdır. Bu açıdan ders kitabının öğretim programına ve kanıt temelli öğretim anlayışına ters düştüğü söylenebilir.

7. ünitenin ikinci kazanımın ise öğrencilere alt düzey becerileri kazandırmaya yönelik kavrama düzeyinde olduğu söylenebilir. Kazanıma dair verilen kaynaklara ve ara metinlere yönelik sorular tarihsel analiz ve yorum 
ve değişim ve sürekliliği algılama becerisi kazandırmaya yöneliktir. 2. ünitedeki kazanıma benzer olarak kazanım kavrama düzeyinde olmasına rağmen içerik olarak kavrama düzeyi ihlal edilmiş ve üst düzey içerik hazırlanıp sorular yönlendirilmiştir.

Kazanım, beceri ve etkinlik arasında uyum olmayanların yanı sıra kazanım, beceri ve etkinlik açısından dengeyi yakalamış olan kazanımlar da yer almaktadır. Bu kazanımlara tablo 4'te yer verilmiştir.

Tablo 4. Kazanım, Beceri ve Etkinlik Arasında Uyum Olanlar

\begin{tabular}{lll}
\hline Kazanım & Beceri & Etkinlik \\
\hline $\begin{array}{l}\text { 2.2. Büyük Millet Meclisinin açlış } \\
\text { sürecini ve sonrasında meydana } \\
\text { gelen gelişmeleri kavrar. }\end{array}$ & Tarihsel Kavrama & $\begin{array}{l}\text { 1. Etkinlik: Müze Etkinliği } \\
\text { 2. Etkinlik: İstiklal Mahkemeleri hakkında araştırma } \\
\text { 3. Etkinlik: Farklı kaynakların kullanımına yönlendirile- } \\
\text { rek Milli Mücadele basını hakkında araştırma ve sunum } \\
\text { yapmak. }\end{array}$ \\
\hline $\begin{array}{l}\text { 4.2.Atatürk Dönemi'nde (1923-1938) } \\
\text { Türkiye Cumhuriyeti'nin dış politika- } \\
\text { sindaki başlıca gelişmeleri açılar. }\end{array}$ & $\begin{array}{l}\text { Tarihsel Kavrama } \\
\text { Tegrihsel analiz ve yorum ve sürekliliği } \\
\text { algılama }\end{array}$ & $\begin{array}{l}\text { 7 etkinlik verilmiştir. } \\
\text { Türk-Yunan ilişkilerinin tarihî seyrini göz önünde } \\
\text { bulundurarak dostluk, düşmanlık, komşuluk,iyi niyet, } \\
\text { siyasi gerçeklik gibi kavramların tartışllığı bir drama } \\
\text { çalışması yapınız. }\end{array}$ \\
\hline $\begin{array}{l}\text { 8.2.1990 sonrasında meydana gelen } \\
\text { siyasi gelişmeleri Türkiye'ye etkileri } \\
\text { ve dünya siyasi konjonktürü bağla- } \\
\text { mında analiz eder. }\end{array}$ & Tarihsel analiz ve yorum & $\begin{array}{l}\text { Tetkinlik verilmiştir. } \\
\text { Kazanımda geçen kuruluşlara dair afiş çalışması }\end{array}$ \\
\hline
\end{tabular}

2. ünitenin ikinci kazanımının yüklemine bakıldığında kazanımın kavrama düzeyinde ele alındığı ifade edilebilir. Kaynaklara yöneltilen sorular genellikle kavrama düzeyindedir. Kazanıma dair sunulan etkinliklerin niteliğine bakıldığında etkinliklerden ikisi öğrencinin konu hakkında araştırma yapmasını sağlayacak düzeyde biri ise geçmişe dair birinci el kaynaklara ulaşıp dönemi şartları ile değerlendirilmesini sağlayacak düzeydedir.

4. ünitenin ikinci kazanımının ise daha çok kavrama ve analiz düzeyinde ele alındığ 1 söylenebilir. Kazanıma yönelik verilen kaynaklara yöneltilen sorularda öğrencilerin tarihsel kavrama, tarihsel analiz ve yorum ve değişim ve sürekliliği algılama becerisi kazanmasının amaçlandığı söylenebilir. Aynı zamanda verilen etkinlik kazanıma uygun olarak üst düzey beceri kazandırmaya yöneliktir ve kazanım, beceri ve etkinlik bağlamında kanıt temelli eğitim anlayışına uygun hazırlandığı ifade edilebilir.

8. ünitenin ikinci kazanımında ise kazanım analiz düzeyindedir ve kazanım öğrencilerin çıkarımlarda bulunmasına ve öğrencilere üst düzey beceriler kazandırmaya yöneliktir. Kazanıma yönelik hazırlanan kaynaklara yö- 
neltilen sorularda tarihsel kavrama ve tarihsel analiz ve yorum becerisi kazandırmanın amaçlandığı söylenebilir. Öğretim programında verilen kanıt temelli öğretim anlayışna göre becerilerin kazandırılması bağlamında öğrencinin kavrama düzeyinden başlayıp analiz düzeyine ulaşması hedefi ile örtüştügü söylenebilir. Verilen etkinliklerden biri olan afiş çalışması sınıf içi etkinlik olması bakımından ve analiz düzeyinde öğrencinin yaratıcı yanını ortaya çıkarması bakımından kazanıma uygundur.

\section{Tartışma ve Sonuç}

Ülkemizde yapılandırmacı eğitim anlayışı birlikte tarih öğretiminde yeni yaklaşımlar kullanılmaya başlanmıştır. Bu yaklaşımlardan biri, ilk olarak İngiltere'de kullanılan, kanıt temelli tarih öğretimidir. Kanıt temelli tarih öğretimi ile birlikte öğrenciden küçük birer tarihçi gibi becerilere sahip olması ve kendi tarihsel bilgisini inşa etmesi beklenmektedir. Bu süreçte öğrenciler tarihi olay ve olgulara dair farklı bakış açılarına sahip birinci elden ve ikinci elden kaynaklarla/kanıtlarla karşılaşarak bilgi inşa sürecini gerçekleştirmektedir.

Türkiye'de 2018 yılında yenilenen öğretim programıla birlikte Ortaöğretim T.C. İnkılap Tarihi ve Atatürkçülük ders kitabı kanıt temelli öğrenme anlayışına göre hazırlanmıştır. Ders kitabı kanıt temelli öğrenme anlayışının prensiplerine göre incelendiğinde birinci el ve ikinci el kaynaklar/kanıtlar arasında eşit dağılımın olmadığı sonucu ortaya çıkmıştır. Kitapta ağırlıklı olarak genel ağ kaynakları ile birlikte ikinci el kaynaklar kullanılmıştır. Benzer şekilde Yazıcı (2019) 9. sınıf tarih ders kitabında ikincil kaynakların tercih edildiği, 10. sınıf tarih ders kitaplarında ise ikincil kaynaklara birincil kaynaklardan daha fazla yer verildiği sonucuna ulaşmış; Kibar (2019) da tarih ders kitaplarında birinci elden kantların daha az, ikinci elden kanitların daha fazla kullanıldığını gözlemlemiştir. Öğretim programında geçen farklı bakış açılarına sahip kaynak kullanımı söylemi ile uyuşan bir kaynak görülmemiştir. Yazıcı'nın (2019) çalışmasında da benzer sonuçlara ulaşılmış, tarih ders kitaplarındaki kanıtların farklı yorum ya da bakış açısı yansıtmadığı belirlenmiş; Kibar'ın (2019) araştırmasında tarih ders kitaplarındaki kanıtların çoğunlukla ana anlatıyı destekleyecek metinlerden seçildiği sonucuna ulaşılmıştır. Başka bir ifadeyle ilgili ders kitabında kaynakların/kanıtların tek bir bakış açısına sahip olduğu ifade edilebilir. Fines (1994) 
ikinci el materyallerin duygulara, düş gücüne ya da kararlara, dikkatle ele alınan birincil kaynaklar kadar nüfuz edemeyeceği görüşündedir. Birinci el kaynak niteliğinde görseller (gazete haberleri, fotoğraflar vb.) bulunmaktadır fakat bunlar kitapta birinci el kaynak sınıflandırılmasına dâhil edilmemiştir. Görsel olarak verilmiş ve öğrencinin sorgulamasına yönelik bir yaklaşım bulunmamaktadır (akt. Yapıcı, 2006: 25).

Kitapta birinci el ve ikinci el kaynaklara/kantlara yönelik kanıtı sorgulama soruları bulunmaktadır. Bu sorular ile öğrencilere küçük birer tarihçi gibi tarihsel düşünme becerileri kazandırılmaya çalışılmaktadır. Kitapta kanıtı sorgulama soruları ile ağırlıklı olarak tarihsel analiz ve yorum becerisi kazandırmanın amaçlandığı söylenebilir. Bu beceri kazandırılırken öğretim programında yer alan çok boyutlu düşünmeyi sağlayacak kaynakların olmaması öğretim programı ile ders kitabının çeliştiğini göstermektedir. Öğrencinin tarihsel analiz ve yorum becerisini kazanabilmesi için öncelikle kavrama düzeyinde beceriyi kazanması gerekmektedir. Öğretim programında da ifade edilen bu yaklaşım ders kitaplarına yansımamıştır (TTKB,2018).

Husband'a (1996:13-14) göre geçmişin deneyimleri ve ürünleri, eleştirel bakış açısıyla yorumlanır ve geçmiş inşa edilmeye çalışılır. Geçmişin kanıtları, soru sormaya başlanıncaya kadar tam olarak kanıt sayılmazlar. Tarihi anlayışın gelişimi daima kendimizin bu günü ile her ne şekilde olursa olsun geçmişin geride bıraktığı kanıtları arasındaki aktif diyaloğun sonucudur. Kitapta verilen kaynakların birçoğunda kanıt sorgulama sorusu bulunmamaktadır. Bu yaklaşımdan yola çıkarak kanıtların anlaşılmasında ve sorgulanmasında eksiklik olduğu söylenebilir. Kaynakların öğrenci tarafından algılanması, kendi bilgisini inşa ederken eleştirel yaklaşmasının göz ardı edildiği söylenebilir.

Öğretim programında verilen kazanımlar kavrar, açılar, analiz eder, değerlendirir gibi yüklemlerden oluşmaktadır. Buradan yola çıkarak ders kitabının içeriği ve kaynakları verilmektedir. Ders kitabına bakıldığında ise kazanımlar ve beceriler arasında anlamlı bir ilişki olmadığı görülmüştür. Öğrenciye, kavrama düzeyindeki bir kazanıma dair bilgi seviyesinde en alt düzeyde beceri kazandırmadan, öğrenciden analiz düzeyinde bir çıarımda bulunması istenmektedir. Hazırlanan öğretim programı ile ders kitabının kazandırmaya çalıştığı beceriler, birinci ve ikinci el kaynaklar/kanıtlar ve etkinlikler arasında uyum olmadığı söylenebilir. 
EXTENDED ABSTRACT

\title{
Evidence-Based Learning Approach in History Textbooks: Secondary Education Turkish Republic History of Revolution and Kemalism Textbook Example
}

\author{
Mehtap Koldaş - Akif Pamuk \\ Marmara University, Marmara University
}

With the new understanding of history which emerged in England in the 1970 's, the student centrism was built on basic notions such as history study, developing historian skills, interpreting evidence, analysing evidence, causality or empathy (Ata, 1999, p.2). Along with the new history teaching that was developed against traditional history teaching, some methods such as experience, problem solving, and exploring were used and this is aimed for the students to acquire historical meanings. The student, who is given the role of a historian, needs to understand how the past is interpreted by historians while questioning historical events and facts. In this context, history teachers see their students as little historians. According to this point of view, realising historical understanding by the students is possible by the use of historical evidence and documents. This situation also contributes to students' acquisition skills such as historical imagination and historical sensitivity (Dilek, 2007, p.71).

Along with the constructivist education approach, it is aimed that students could gain historical thinking skills in their history lessons. In order to gain these skills, history textbooks are prepared according to evidencebased history teaching approach, which is one of the most preferred methods, and the questions are asked according to the evidences. Students are expected to gain new skills through the given questions and activities. In this context, the problem question of the research is "How is the evidence-based learning used in history textbooks?" The sub-problems of the research were as follows: 
1. What types of evidence are used in the evidence-based learning in history textbooks?

2. Which skills are gained with the evidence-based learning in history textbooks?

3. What is the relationship between acquisition, skill and activity in the evidence-based learning in history textbooks?

In this study, case study which is one of the qualitative research designs was preferred. The case study is "about examining a current case study or situation deeply in an authentic setting when the boundaries between context and situation are not clear"(Yin,2014, akt.Saban ve Ersoy, 2016). In order to analyse the problem question in depth, Turkish Republic History of Revolution and Kemalism Textbook of 12th Grades was examined by the training committee in the 2019-2020 academic year. The 12th grade History of Revolution course deals with a process that is close to the present day in terms of subject and first-hand resources are easier to access and, consequently, first-hand resources are more likely to be used.

Document analysis which is one of the qualitative research data collection tools, was preferred in this state of the study. The reason why document analysis was preferred is to reveal how the evidence-based education approach was applied in the textbook.

Descriptive analysis and content analysis were used to analyse the data. By examining the $12^{\text {th }}$ Grade Turkish Republic History of Revolution and Kemalism textbook, first-hand, second-hand and general network resources were determined; as a result of the examination, the skills acquired were analysed and the relationship between acquisition, skill and activity was interpreted.

The evidence that was used in the Unit 1 of $12^{\text {th }}$ Grade Turkish Republic History of Revolution and Kemalism Textbook are divided into three as first hand resources, second hand resources and general network resources by the authors of the textbook. General network resources are taken from the articles prepared on the websites such as dergipark, ulakbim unv, atam.org. General network resources were mostly second-hand resources but first-hand resources are used. There are images in the textbook that can be seen as a first-hand source without being given as evidence. 
It is aimed for the students to gain historical thinking skills by the activities and the questions directed against the evidences given in the $12^{\text {th }}$ Grade Turkish Republic History of Revolution and Kemalism textbook which were prepared according to the evidence-based education. When the questions and activities are examined, it could be said that they are trying to provide the skills of historical understanding, historical analysis and interpretation, perception of change and continuity, and establishing cause and effect relationship.

The questions about the resources and mid- texts on achievement are intended to gaining the ability to perceive historical analysis and interpretation, change and continuity. Preparing high-level content and asking questions for an attainment shows that it is not suitable for the outcome. Moreover, the activity about achievement is not an activity that can be done in the classroom. It could be said that with the understanding of evidence-based education, it is aimed at improving social learning and increasing the interaction between students as the student gains skills.

The Turkish Republic History of Revolution and Kemalism textbook for $12^{\text {th }}$ Grade was prepared according to the evidence-based education together with the renewed curriculum in Turkey in 2018. When the textbook is examined according to the principles of evidence-based education; it is concluded that there is no equal distribution between first-hand and second-hand resources. In the book, second-hand sources are mainly used with general network resources. There is no source that is compatible with the discourse of using sources with different perspectives in the curriculum. It can be stated that the sources have a single point of view. According to Fines (1994), second-hand materials could not affect emotions, imagination or decisions as much as first-hand sources which are handled in a careful manner. First-hand resource images (newspaper articles, photographs, etc.) are available, but these are not included as a primary resource in the book. They are given visually but there is no approach to the students' inquiry.

There are questions in the book for first hand and second hand resources. With these questions are intended for the students to gain historian skills. It can be said that it is aimed to provide historical analysis and interpretation skills in the context of the questions examined in the book. Lack of resources to enable multidimensional thinking given in the pro- 
gram shows that the curriculum and the textbook are in conflict with this skill. In order for the student to gain historical analysis and interpretation skills, it is necessary to acquire the skill at the level of comprehension. This approach, which is also expressed in the curriculum, is not reflected in the textbooks (TTKB,2018).

\section{Kaynakça / References}

Alabaş, R. (2007). İköğretim 6. Sinff Sosyal Bilgiler dersinde kanıt temelli öğrenme modeli: Bir eylem araştırması. Yayımlanmamış Yüksek Lisans Tezi, Marmara Üniversitesi Ĕgitim Bilimleri Enstitüsü, İstanbul.

Alaca, E. (2017). Cumhuriyet Dönemi lise tarih ders kitapları üzerine bir değerlendirme. International Online Journal of Educational Sciences, 9(4), 988-1007.

Alaca, E. (2019). Sosyal Bilgiler ders kitabı incelemeleri. Ed. (T. Çelikkaya, Ç. Öztürk Demirbaş, T. Yıldırım, H. Yakar). Yeni Program ve Ders İçeriklerine Göre Sosyal Bilgiler Öğretimi II içinde. (s.1-21). Ankara: Pegem Akademi Yayınları.

Büyüköztürk, Ş., Çakmak E., Akgün Ö., Karadeniz Ş. ve Demirel F. (2012). Bilimsel araştrma yöntemleri. Ankara: Pegem Akademi Yayınları.

Çolak, K. (2008). Tarih dersi snnav sorularmin bloom taksonomisi'nin bilişsel alan dïzeyi açısından sınıflandırnlması. Yayımlanmamış Yüksek Lisans Tezi, Karadeniz Teknik Üniversitesi Sosyal Bilimler Enstitüsü, Trabzon.

Demirtaş, B. (2019). Ortä̈̆gretim 12. sinıf T.C. İnklap Tarihi ve Atatürkçülük ders kitabı. Ankara: Mevsim Yayincllik.

Dilek, D. (2007). Tarih derslerinde öğrenme ve düşünce gelişimi. Ankara: Nobel Yayın.

Dilek, D. ve Alabaş, R. (2010). Öğrencilerde Tarihsel Düşünce Gelişimi. Ed. (M. Safran), Tarih Nasıl Öğretilir? Tarih Öğretmenleri Iç̧in Özel Öğretim Yöntemleri içinde. (s.123-130). İstanbul: Yeni İnsan Yayınevi.

Doğan, Y. (2007). Sosyal Bilgiler öğretiminde tarihsel yazll kamıtlarm kullanımı. Yayımlanmamış Doktora Tezi, Gazi Üniversitesi Eğitim Bilimleri Enstitüsü, Ankara.

Husbands, C. (1996) What is history teaching? Open University Press, Buckingham.

Kabapınar, Y. (Ed.) (2019). Kimlik belirleyen derslerde kamt temelli öğrenme. Ankara: Pegem Akademi Yayınları.

Kibar, H. (2019). Ortaöğretim tarih ders kitaplan kanıt temelli öğrenme yaklaşımının neresindedir?:Bir saptama çalışması. Yayımlanmamış Yüksek Lisans Tezi, Marmara Üniversitesi Eğitim Bilimleri Enstitüsü, İstanbul.

Pamuk, A. (2014). Kimlik ve tarih: Kimliğin inşasında tarihin kullanımı. İstanbul: Yeni İnsan Yayınevi. 
Pamuk, İ. (2020). Almanya' da hayat bilgisi ders kitaplarında tarihin kullanımı. Turkish History Education Journal, 9 (1), 209-231. DOI: 10.17497/tuhed.

Saban, A. ve Ersoy, A. (2016). Eğitimde nitel araştırma desenleri. Ankara: Anı yayınc1lik.

Talim ve Terbiye Kurulu Başkanlığı (TTKB), (2018). Ortaöğretim T. C. Inkılap tarihi ve Atatürkçülük dersi öğretim programı. Ankara: T.C. MEB Talim Terbiye Kurulu Başkanlığı.

Yapıcı, G. (2006). Dört kültürde tarih öğretimi yaklaşımı: Ingiltere, Fransa, Isviçre ve Türkiye örnekleri. Yayımlanmamış Yüksek Lisans Tezi, Marmara Üniversitesi Eğitim Bilimleri Enstitüsü, İstanbul.

Yazıcı, F. (2019). Güncel tarih öğretim programı ve ders kitaplarında kanıt temelli öğretim: ‘Türk usulü bir yaklaşım mı?’ Ed. (Y. Kabapınar), Kimlik Belirleyen Derslerde Kanıt Temelli Öğrenme içinde. (s.75-101). Ankara: Pegem Akademi Yayınları.

Yıldırım, A. ve Şimşek, H. (2013). Sosyal bilimlerde nitel araştırma yöntemleri. Ankara: Seçkin Yayıncılik.

\section{Kaynakça Bilgisi / Citation Information}

Koldaş, M. ve Pamuk, A. (2020). Tarih ders kitaplarında kanıt temelli öğrenme yaklaşımı: Ortaöğretim T.C. İnkılap Tarihi ve Atatürkçülük ders kitabı örneği. OPUS-Uluslararası Toplum Araştırmaları Dergisi, 16(Eğitim Ve Toplum Özel Sayıs1), 6413-6436. DOI: 10.26466/opus.825129 